\title{
Prediksi Gejala Autism Spectrum Disorders pada Remaja Menggunakan Optimasi Particle Swarm Optimization dan Algoritma Support Vector Machine
}

\author{
Ilham Kurniawan ${ }^{1 *}$, \\ ${ }^{1}$ Sistem Informasi;Universitas Bina Sarana Informatika; Jl. Banten No.1 Karangpawitan, \\ Karawang Barat; e-mail: ilham.imk@bsi.ac.id \\ * Korespondensi: e-mail: ilham.imk@bsi.ac.id
}

Diterima: 20 April 2020 ; Review: 5 Mei 2020; Disetujui: 12 Mei 2020

Cara sitasi: Kurniawan I. 2020. Prediksi Gejala Autism Spectrum Disordes pada Remaja Menggunakan Optimasi Particle Swarm Optimization dan Algoritma Support Vector Machine. Informatics for Educators and Professionals. 4(2): 113-122.

\begin{abstract}
Abstrak: Telah ada peningkatan prevalensi diagnosis Autism Spectrum Disorder (ASD) secara global selama dekade terakhir. Perkiraan prevalensi ASD yang diperbarui dan keseluruhan di Asia akan membantu para profesional kesehatan untuk mengembangkan strategi kesehatan masyarakat yang relevan. Dalam penelitian ini, mengusulkan metode untuk prediksi gejala ASD menggunakan teknik integrasi seleksi fitur PSO dan algoritma Support Vector Machine. Penelitian ini menggunakan dataset dari $\mathrm{UCl}$ repository. Model yang diusulkan meliputi penerapan seleksi fitur menggunakan particle swarm optimization (PSO), dengan algoritma pengklasifikasi. Hasil akhir akan dilakukan perbandingan pengujian dan analisa terhadap model prediksi yang memiliki tingkat akurasi tertinggi atau terbaik dalam prediksi gejala ASD. Dalam penelitian ini menggunakan dataset $\mathrm{UCI}$ repository yaitu data ASD pada remaja, data tersebut memiliki jumlah data sebanyak 104 instance dan 21 atribut, 41 orang tidak menderita ASD dan 63 orang menderita ASD, tools yang digunakan untuk menerapkan model usulan menggunakan aplikasi Weka versi 3.8.4. Untuk mengetahui model usulan yang diajukan pada penelitian ini, pertama menguji dengan klasifikasi tunggal SVM, dan kedua, menguji dengan seleksi fitur PSO dan algoritma klasifikasi SVM. Untuk mengetahui apakah seleksi fitur PSO berpengaruh terhadap performa algoritma klasifikasi SVM. Pengujian pertama, nilai akurasi yang dihasilkan oleh algoritma klasifikasi SVM adalah sebesar $89.42 \%$, dan nilai AUC sebesar 0.891. Berdasarkan pengujian yang kedua yaitu menggunakan seleksi fitur PSO, seleksi fitur PSO dapat meningkatkan performa algoritma klasifikasi SVM sebesar 2,88\% dan nilai AUC sebesar 0,024 .
\end{abstract}

Kata kunci: Autism Spectrum Disorder, Particle Swarm Optimizatio, Support Vector Machine

Abstract: There has been an increase in the prevalence of diagnoses of Autism Spectrum Disorder (ASD) globally over the past decade. Updated and overall ASD prevalence estimates in Asia will help health professionals to develop relevant public health strategies. In this study, proposing a method for ASD symptom prediction using PSO feature selection integration techniques and the Support Vector Machine algorithm. This study uses a dataset from the UCI repository. The proposed model includes the application of feature selection using particle swarm optimization (PSO), with the classification algorithm. The final result will be a comparison test and analysis of prediction models that have the highest or best accuracy in predicting ASD symptoms. In this study using the $\mathrm{UCl}$ repository dataset, ASD data on adolescents, the data has 104 data and 21 attributes, 41 people do not suffer from ASD and 63 people suffer from $A S D$, tools used to implement the proposed model using the Weka application version 3.8.4 . To find out the proposed model proposed in this study, firstly testing with SVM single classification, and secondly, testing with PSO feature selection and SVM classification algorithm. To find out whether the PSO feature selection affects the performance of the SVM classification algorithm. The first test, the accuracy value generated by the SVM classification algorithm is $89.42 \%$, and the AUC value is 0.891. Based on the second test using PSO feature selection, PSO feature 
selection can improve the performance of the SVM classification algorithm by $2.88 \%$ and the AUC value of 0.024 .

\section{Keywords: Autism Spectrum Disorder, Particle Swarm Optimizatio, Support Vector Machine}

\section{Pendahuluan}

Gejala gangguan Autism Spectrum Disorders (ASD) termasuk kesulitan sosial, kesulitan komunikasi verbal dan nonverbal, dan perilaku stereotip atau berulang [1]. Gangguan spektrum autisme (ASD) terdiri dari beberapa gangguan perkembangan saraf kompleks yang menyatu di sekitar gangguan dalam kemampuan komunikatif, fungsi sosial, dan perilaku kaku atau berulang. Cacat yang menyebar ini digambarkan sebagai gangguan spektrum karena variasi yang cukup besar dalam bagaimana individu memanifestasikan gejala [2]. Prevalensi ASD pada populasi global diperkirakan sekitar $1 \%$, tetapi jumlah itu telah meningkat selama dekade terakhir. Keragaman gejala, dan gangguan perilaku adaptif dalam populasi ASD mempersulit pengembangan perawatan yang efektif dan peningkatan tindakan diagnostik [3]. Selain itu, ada beberapa bukti yang menunjukkan bahwa kebutuhan kesehatan orang dengan gangguan spektrum autisme kadang-kadang diabaikan, oleh karena itu, mengakibatkan tingkat kepuasan yang rendah terhadap layanan kesehatan semakin diperburuk oleh hambatan dalam mengakses perawatan medis [4].

Anak-anak dengan ASD, keluarga mereka, dan masyarakat menderita beban ekonomi yang berat. Selain itu, anak-anak ini secara substansial dipengaruhi oleh hasil terkait ASD, termasuk gangguan yang berhubung [5], dan bullying [6][7]. Akumulasi bukti menunjukkan bahwa jika anak-anak dengan ASD diobati sedini mungkin, beban pada masyarakat akan sangat berkurang [8]. Beberapa penelitian menunjukkan bahwa gejala depresi dan kecemasan yang terjadi secara bersamaan dapat memperburuk gejala inti ASD di seluruh perkembangan, yang mengarah pada berkurangnya komunikasi, penarikan sosial, dan peningkatan agitasi psikomotorik, perilaku stereotip dan obsesif [9].

Algoritma Particle Swarm Optimization (PSO), adalah metode yang sangat efektif untuk masalah multimoda. PSO populer karena mudah diimplementasikan, dan memiliki kemampuan optimasi yang kuat. Efisiensi dalam menyelesaikan masalah optimasi yang kompleks telah menarik penelitian yang signifikan [10]. Algoritma PSO berasal dari studi tentang sifat perilaku burung predator. Prinsip dasar algoritma PSO adalah bahwa setiap burung diabstraksi sebagai partikel, dan hasil yang dioptimalkan sesuai dengan posisi partikel di ruang pencarian [11]. Dalam setiap langkah iterasi, partikel diperbarui dengan melacak dua ekstrem berikut: satu adalah posisi terbaik dari solusi lokal dan satu lagi adalah posisi terbaik dari solusi optimal global. Melalui pengalaman belajar mereka dan pertukaran semua informasi partikel, PSO menentukan langkah selanjutnya dari kecepatan dan arah penerbangan, dan secara bertahap bergerak menuju solusi optimal global. Dengan demikian, pengenalan algoritma PSO sebagian besar dapat meningkatkan kinerja algoritma Support Vector Machine (SVM) [12].

Support Vector Machine termasuk dalam kategori pembelajaran komputasi dalam kecerdasan buatan. Support Vector Machine adalah teknologi machine learning yang dikembangkan pada pertengahan 1990-an. Dibandingkan dengan teknologi pembelajaran tradisional, ia memiliki dasar teori yang kuat. Dilihat dari sejumlah besar aplikasi, kinerjanya memang lebih unggul daripada metode tradisional. Support Vector Machine menciptakan dan memelihara catatan terbaik pada banyak masalah khusus seperti pengenalan angka tulisan tangan, klasifikasi teks, dan lain-lain. Support Vector Machine memiliki kemampuan belajar yang kuat dan kemampuan generalisasi [13][14]. Support Vector Machine adalah metode pembelajaran beberapa-dugaan baru dengan dasar teori yang kuat, dan dapat secara efisien mewujudkan "penalaran transduksi" dari sampel pelatihan hingga pengujian sampel. Support Vector Machine dapat sangat menyederhanakan klasifikasi dan masalah regresi yang biasa [15].

Dalam penelitian ini, mengusulkan metode untuk prediksi gejala ASD menggunakan teknik integrasi seleksi fitur PSO dan algoritma Support Vector Machine. Penelitian menggunakan dataset dari UCI repository. 


\section{Metode Penelitian}

Model yang diusulkan meliputi penerapan seleksi fitur menggunakan particle swarm optimization (PSO), dengan algoritma pengklasifikasi. Hasil akhir akan dilakukan perbandingan pengujian dan analisa terhadap model prediksi yang memiliki tingkat akurasi tertinggi atau terbaik dalam prediksi gejala ASD. Berikut ini merupakan kerangka model penelitian yang diusulkan.

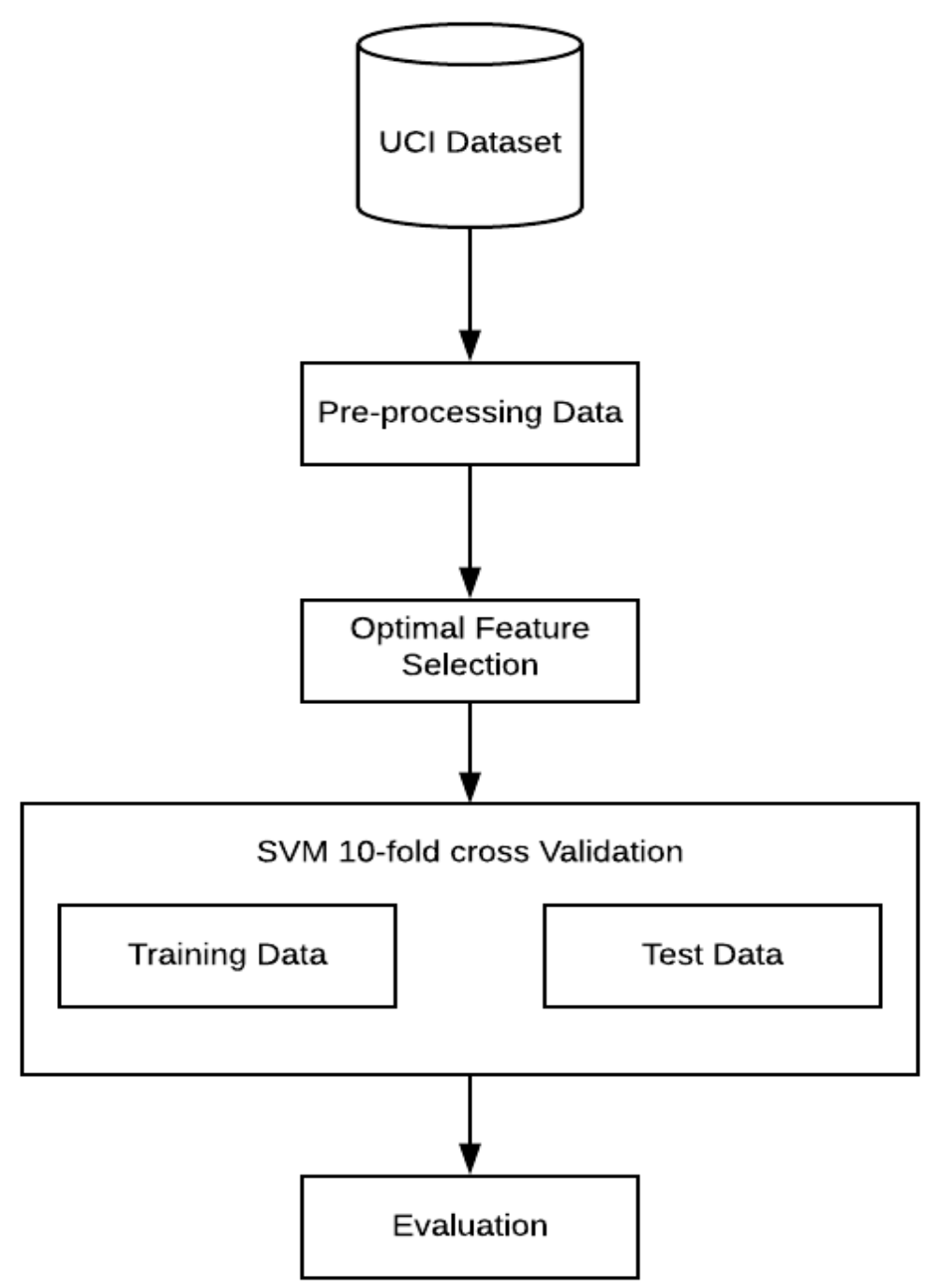

Sumber: K. Shankar, dkk (2020)

Gambar 1. Metode Penelitian

Dari kerangka model penelitian[14] yang telah diusulkan pada Gambar 1. Metode Penelitian, dapat dijelaskan sebagai berikut : a). UCI Dataset adalah Dataset yang digunakan dalam penelitian ini, merupakan dataset dari UCI repository, yaitu data ASD pada remaja yang memiliki 104 instance, 21 attribut. b). Pre-processing Data adalah Teknik pre-processing data yang digunakan pada penlitian ini yaitu, menggunakan Replace Missing Value, gunanya untuk mengganti semua nilai yang hilang menggunakan nilai rata-ratas setiap atribut. b). Optimal feature selection Feature selection yang digunakan dalam penelitian ini, yaitu menggunakan teknik seleksi fitur particle swarm optimization. PSO adalah teknik komputasi evolusioner dalam mencari solusi terbaik dengan mensimulasikan pergerakan burung dalam satu kawanan. Populasi burung disebut segerombolan, dan anggota populasi adalah partikel [16]. c). SVM 10- 
fold cross validation, Pada penelitian ini diusulkan menggunakan algoritma SVM dengan 10-fold cross vallidation, validasi menggunakan 10-fold cross validation dilakukan dengan membagi dataset menjadi 10 bagian, satu bagian sebagai data uji, sedangkan bagian lain sebagai data latih. Proses validasi dilakukan berulang, mulai bagian pertama sebagai data uji sampai bagian kesepuluh, sehingga semua data dalam dataset diuji. Tujuan dari validasi adalah menghasilkan kinerja model prediksi gejala ASD pada remaja. d). Evaluation, Kinerja model prediksi gejala ASD pada remaja diukur berdasarkan nilai akurasi, dan nilai AUC. Nilai AUC dapat dijadikan ukuran untuk melihat model yang terbentuk. Area Under ROC Curve (AUC) digunakan untuk memberikan metrik numerik single untuk dapat membandingkan kinerja dari model, nilai AUC berkisar dari 0 sampai 1 dan model yang lebih baik prediksinya adalah yang mendekati nilai 1.

Dalam penelitian ini, metode yang diusulkan dievaluasi dengan menggunakan efektivitas classifier berdasarkan confusion matrix dengan evaluasi utama adalah AUC seperti yang digunakan oleh[17], [18], [19], [20], [21], [22], [23] dan [24].

\section{Hasil dan Pembahasan}

Dalam penelitian ini dataset yang digunakan merupakan dataset $\mathrm{UCI}$ repository yaitu data ASD pada remaja, data tersebut memiliki jumlah data sebanyak 104 instance dan 21 atribut, 41 orang tidak menderita ASD dan 63 orang menderita ASD, yang akan disajikan dalam Tabe 1 dan Tabel 2.

Tabel 1. Dataset ASD

\begin{tabular}{|c|c|c|c|c|c|c|c|c|c|c|c|c|c|c|c|}
\hline id & A1 & A2 & A3 & A4 & A5 & A6 & A7 & A8 & A9 & $\ldots$ & ethnicity & austim & age & \multicolumn{2}{|c|}{ Class/ASD } \\
\hline 0 & 1 & 0 & 0 & 0 & 1 & 1 & 1 & 1 & 1 & 1 & $\mathrm{~m}$ & yes & 6 & Parent & $\mathrm{NO}$ \\
\hline 1 & 2 & 0 & 0 & 0 & 0 & 0 & 0 & 0 & 0 & 1 & $\mathrm{~m}$ & no & 2 & Relative & $\mathrm{NO}$ \\
\hline 2 & 3 & 0 & 0 & 0 & 0 & 0 & 0 & 0 & 0 & 1 & $f$ & no & 2 & ? & NO \\
\hline 4 & 5 & 1 & 1 & 1 & 1 & 1 & 1 & 1 & 0 & 0 & $f$ & no & 7 & ? & YES \\
\hline 5 & 6 & 1 & 0 & 0 & 0 & 0 & 1 & 0 & 0 & 1 & $f$ & no & 3 & $?$ & $\mathrm{NO}$ \\
\hline 8 & 9 & 1 & 1 & 1 & 1 & 1 & 1 & 0 & 0 & 0 & $\mathrm{~m}$ & yes & 6 & Parent & $\mathrm{NO}$ \\
\hline 9 & 10 & 0 & 1 & 1 & 0 & 0 & 1 & 0 & 0 & 1 & $f$ & no & 4 & Parent & $\mathrm{NO}$ \\
\hline 10 & 11 & 1 & 0 & 0 & 0 & 1 & 1 & 0 & 1 & 1 & $f$ & yes & 5 & Parent & $\mathrm{NO}$ \\
\hline 11 & 12 & 1 & 0 & 0 & 0 & 1 & 1 & 0 & 0 & 1 & $f$ & no & 5 & Self & $\mathrm{NO}$ \\
\hline 12 & 13 & 1 & 0 & 0 & 1 & 1 & 1 & 0 & 1 & 1 & $f$ & no & 7 & Self & YES \\
\hline 13 & 14 & 1 & 1 & 1 & 1 & 1 & 1 & 0 & 1 & 1 & $f$ & no & 9 & Parent & YES \\
\hline
\end{tabular}

Data pada tabel 2 menunjukan deskripsi dari dataset ASD dengan atribute yang terdiri dari age, gender, ethnic, born with jaundice, Family member with PDD, Who is completing the test, Country residence, Used the screening app before, Screening Method type, dan Question 1 answer - Question 10 Answer.

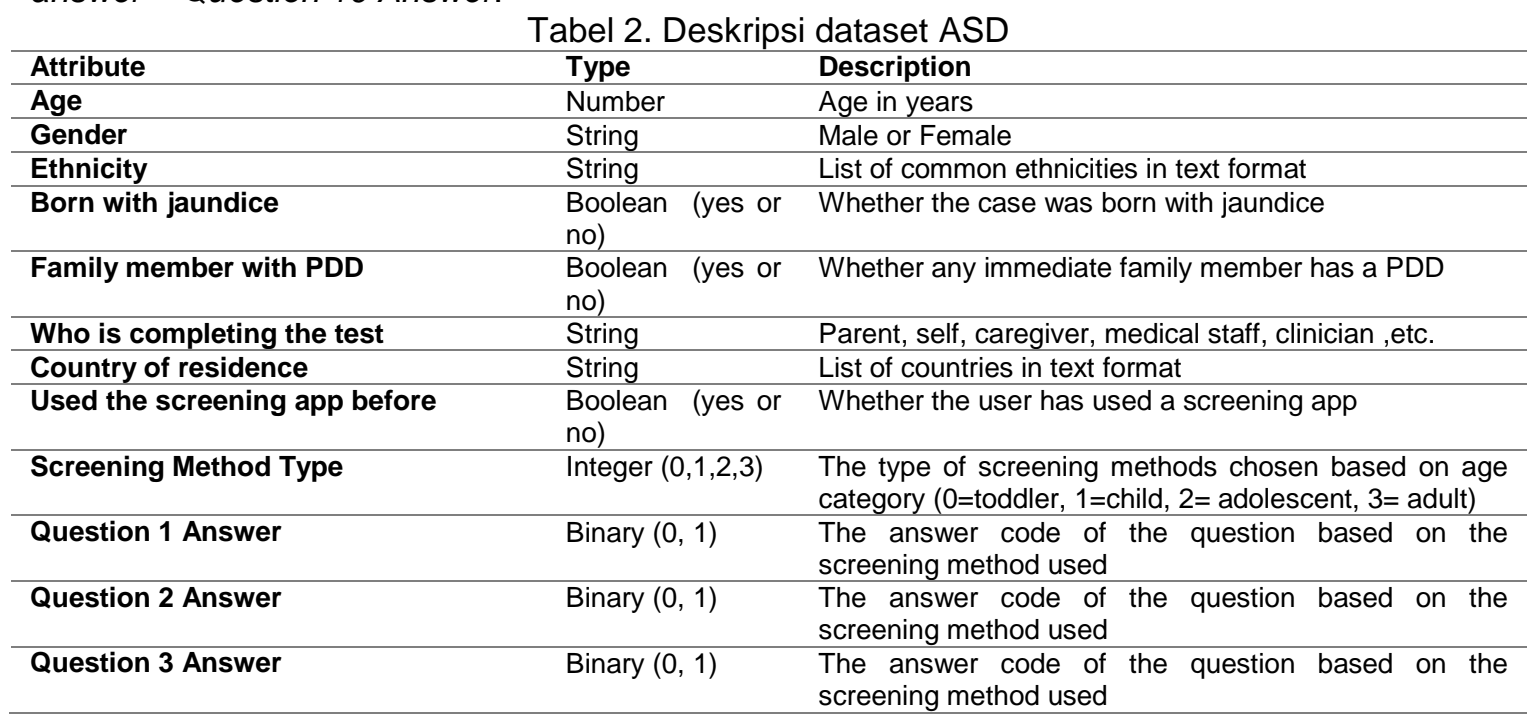




\begin{tabular}{|c|c|c|}
\hline Attribute & Type & Description \\
\hline Question 4 Answer & Binary $(0,1)$ & $\begin{array}{l}\text { The answer code of the question based on the } \\
\text { screening method used }\end{array}$ \\
\hline Question 5 Answer & Binary $(0,1)$ & $\begin{array}{l}\text { The answer code of the question based on the } \\
\text { screening method used }\end{array}$ \\
\hline Question 6 Answer & Binary $(0,1)$ & $\begin{array}{l}\text { The answer code of the question based on the } \\
\text { screening method used }\end{array}$ \\
\hline Question 7 Answer & Binary $(0,1)$ & $\begin{array}{l}\text { The answer code of the question based on the } \\
\text { screening method used }\end{array}$ \\
\hline Question 8 Answer & Binary $(0,1)$ & $\begin{array}{l}\text { The answer code of the question based on the } \\
\text { screening method used }\end{array}$ \\
\hline Question 9 Answer & Binary $(0,1)$ & $\begin{array}{l}\text { The answer code of the question based on the } \\
\text { screening method used }\end{array}$ \\
\hline Question 10 Answer & Binary $(0,1)$ & $\begin{array}{l}\text { The answer code of the question based on the } \\
\text { screening method used }\end{array}$ \\
\hline Screening Score & Integer & $\begin{array}{l}\text { The final score obtained based on the scoring algorithm } \\
\text { of the screening method used. This was computed in an } \\
\text { automated manner }\end{array}$ \\
\hline
\end{tabular}

Sumber: Hasil Penelitian (2020)

Tools yang digunakan untuk menerapkan model usulan menggunakan aplikasi Weka versi 3.8.4. Algoritma yang digunakan pada penlitian ini, yaitu algoritma Support Vector Machine (SVM), SVM adalah algoritma berbasis diskriminasi yang bertujuan untuk menemukan batas pemisahan optimal yang disebut hyperplane untuk membedakan kelas dari satu sama lain. Sampel yang paling dekat dengan hyperplanes ini disebut vektor dukungan, dan perbedaan tersebut dinyatakan sebagai jumlah bobot dari subset sampel yang membatasi kerumitan masalah [25].

SVM bekerja berdasarkan prinsip dasar, yaitu menyisipkan hyper-plane antara kelaskelas dan mengarahkannya sedemikian rupa sehingga menjaganya pada jarak maksimum dari titik data terdekat seperti yang terlihat pada Gambar 2. Data ini menunjuk, yang muncul paling dekat dengan hyper-plane, dikenal sebagai Support Vectors [26].
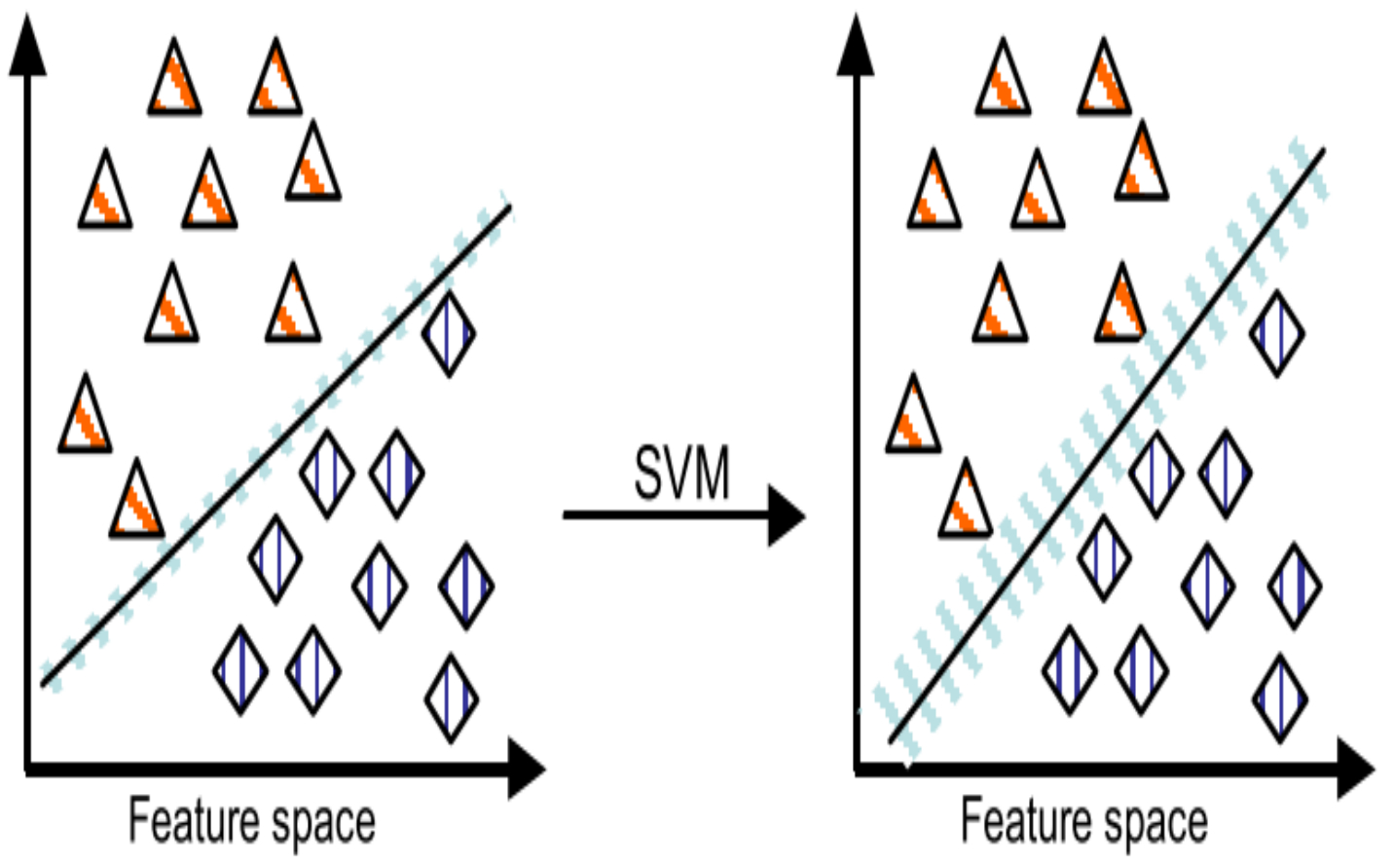

Sumber: M.Sewak, dkk (2007)

Gambar 2. Klasifikasi linear margin maksimum

Dalam penelitian ini juga menggunakan teknik seleksi fitur Particle Swarm Optimization (PSO), Algoritma PSO, yang mensimulasikan perilaku berkelompok burung, pada awalnya 
diusulkan oleh Eberhart dan Kennedy, untuk memecahkan masalah optimasi yang tidak dibatasi. PSO telah berhasil diterapkan pada berbagai masalah karena kesederhanaan dan efisiensi pencarian yang menarik. Algoritma dimulai dengan populasi partikel swarm $\mathrm{N}$ yang diposisikan secara acak di ruang pencarian. Setiap partikel berkerumun memiliki posisi dan kecepatan sendiri. Pada setiap iterasi, posisi dan kecepatan partikel i diperbarui sebagai:

$$
\begin{aligned}
& v \_i d(t+1)=v \_i d(t)+c \_1 r \_1\left(p \_i d(t)-x \_i d(t)\right)+c \_2 r \_2\left(p \_g d(t)-x \_i d(t)\right) \\
& x \_i d(t+1)=x \_i d(t)+v \_i d(t+1)
\end{aligned}
$$

Di mana $d$ adalah dimensi $d$-th dari suatu masalah, $v \_i(t)=\left[v \_i 1(t) v \_i 2(t), \wedge(\ldots), v \_i D(t)\right]$ and $x_{-}$i1 $(\mathrm{t})=\left[\mathrm{x} \_\mathrm{i} 1(\mathrm{t}), \mathrm{x} \_\mathrm{i} 2(\mathrm{t}), \wedge \ldots, \mathrm{x} \_\mathrm{id}(\mathrm{t})\right.$ masing-masing adalah kecepatan dan posisi partikel ke-i pada iterasi $t$-th, Di sini menunjukkan dimensi masalah. $p_{-} i(t)=\left[p_{-} i 1(t), p_{-} i 2(t), \wedge^{\prime} \ldots, p_{-} i D(t)\right]$ adalah posisi terbaik yang ditemukan oleh partikel i-th, $\mathrm{p} \_\mathrm{g}(\mathrm{t})=\left[\mathrm{p} \_\mathrm{g} 1(\mathrm{t}), \mathrm{p} \_\mathrm{g} 2(\mathrm{t}), \wedge \ldots, \mathrm{p} \_\mathrm{gD}(\mathrm{t})\right]$ adalah posisi global terbaik historis yang ditemukan oleh semua partikel. $r_{-} 1$ dan r_2 dua nomor acak yang dihasilkan secara seragam dalam kisaran [0,1], c_1 dan c_2 adalah konstanta positif yang disebut koefisien percepatan [27].

Untuk mengetahui model usulan yang diajukan pada penelitian ini, pertama menguji dengan klasifikasi tunggal SVM, dan kedua, menguji dengan seleksi fitur PSO dan algoritma klasifikasi SVM. Untuk mengetahui apakah seleksi fitur PSO berpengaruh terhadap performa algoritma klasifikasi SVM.

Hasil pengujian dihitung dengan menggunakan Confusion Matrix untuk mencari akurasi, dan AUC. Confusion matrix adalah metode yang digunakan untuk mengukur kinerja model klasifikasi berdasarkan perhitungan objek testing, dimana data hasil prediksi ada diantara dua kelas yaitu menghasilkan kelas positif dan kelas negatif. Untuk proses evaluasi dengan confusion matrix maka akan diperoleh nilai precision, recall, dan accuracy yang didapat dari rumus berikut [28]:

Precision $=\mathrm{TP} /(\mathrm{TP}+\mathrm{Fp})$

Recall $=\mathrm{TP} /(\mathrm{TP}+\mathrm{FN})$

Accuracy $=(T P+T N) /(T P+T N+F P+F N)$

Keterangan:

TP : Jumlah kasus positif yang diklasifikasikan sebagai positif FP : Jumlah kasus negatif yang diklasfikasikan sebagai positif TN ; Jumlah kasus negatif yang diklasifikasikan sebagai negatif FN : Jumlah kasus positif yang diklasifikasikan sebagai negatif

Confusion matrix berisi informasi aktual (actual) dan prediksi (predicted) pada sisitem klasifikasi. Tabel 3 adalah contoh tabel confusion matrix yang menunjukan klasifikasi dua kelas.

Tabel 3. Model Confussion Matrix

\begin{tabular}{ccc}
\hline \multirow{2}{*}{ Classification } & \multicolumn{3}{c}{ Predicted Class } \\
\cline { 2 - 3 } & Class $=$ Yes & Class $=$ No \\
\hline Class $=$ Yes & True Positives (TP) & False Negatives (FN) \\
Class $=$ No & False Positives (FP) & True Negatives (TN) \\
\cline { 2 - 3 }
\end{tabular}

Sumber: M. Y. Kurniawan dan M. E. Rosadi (2017)

Kurva ROC/AUC adalah perangkat dua dimensi yang digunakan untuk menilai kinerja klasifikasi yang menggunakan dua class keputusan, masing-masing objek dipetakan ke salah satu elemen dari himpunan pasangan, positif atau negatif [29]. 


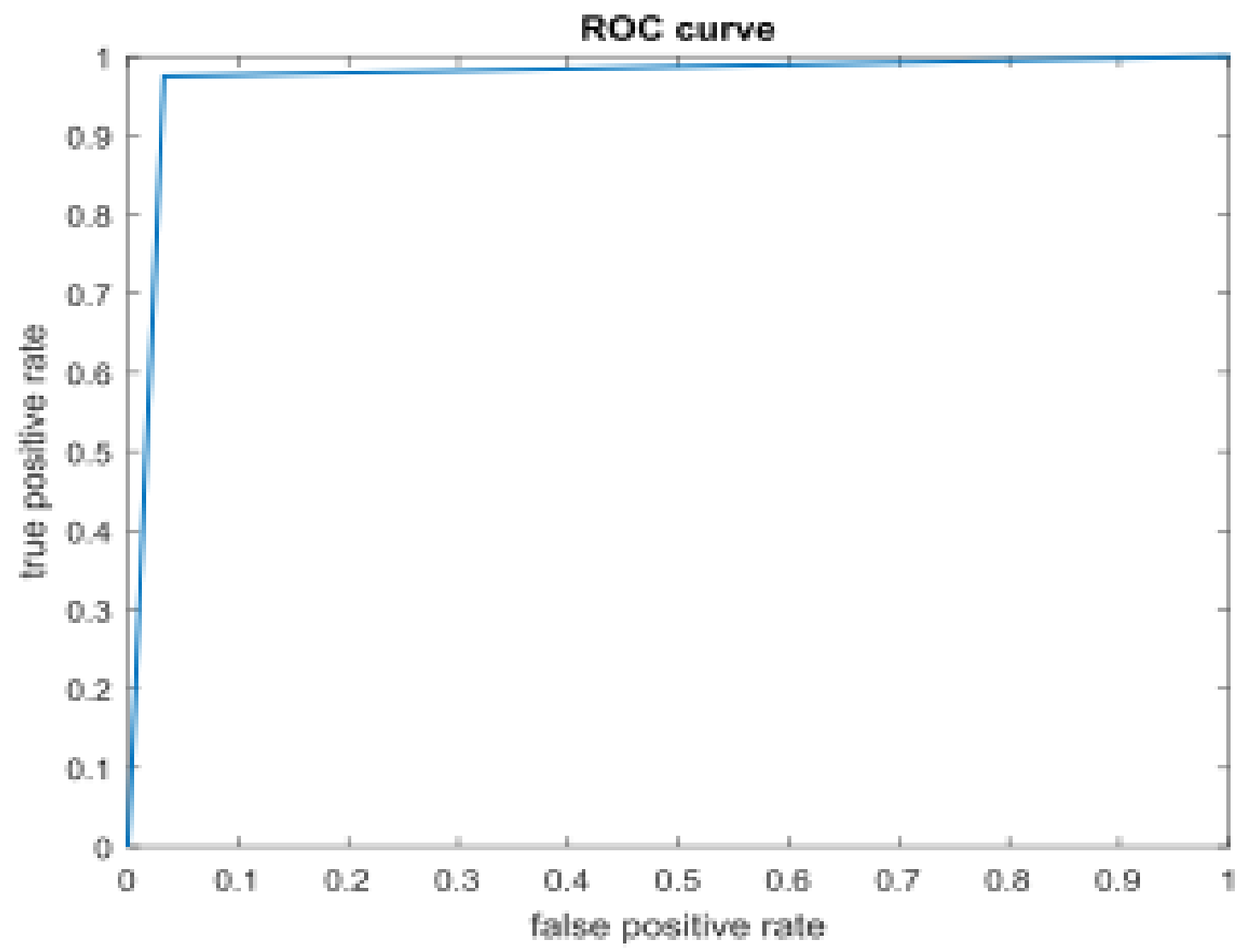

Sumber: R. Wajhillah (2014)

Gambar 3. Grafik ROC (discrete dan continous)

Pada Tabel 4. dapat dilihat nilai akurasi yang dihasilkan oleh algoritma klasifikasi SVM adalah sebesar $89.42 \%$, dan nilai AUC sebesar 0.891 .

Tabel 4. Hasil Kinerja Algoritma Klasifikasi Tunggal SVM Pada Dataset UCI Repositor

\section{Algoritma}

Support Vector Machine Nilai Akurasi

$89.42 \%$
Nilai AUC

0.891

Sumber:Hasil Penelitian (2020)

Pengujian berikutnya yaitu pengujian dengan menggunakan seleksi fitur PSO sebelum diklasifikasikan oleh algoritma klasifikasi SVM, hasil pengujian dihitung dengan menggunakan Confusion Matrix untuk mencari akurasi, dan AUC. Hasil perhitungan diperoleh probabilitas sebagai berikut :

Tabel 5. Hasil Kinerja Seleksi Fitur PSO dan Algoritma Klasifikasi SVM Pada Dataset UCI Repository

\begin{tabular}{ccc}
\hline Algoritma & Nilai Akurasi & Nilai AUC \\
\hline Support Vector Machine & $92.30 \%$ & 0.915 \\
\hline
\end{tabular}

Sumber:Hasil Penelitian (2020)

Berdasarkan tabel diatas pengujian yang kedua yaitu menggunakan seleksi fitur PSO, seleksi fitur PSO dapat meningkatkan performa algoritma klasifikasi SVM sebesar 2,88\% dan nilai AUC sebesar 0,024. Perbandingan hasil penelitian akan disajikan dalam bentuk grafik pada Gambar 4. 


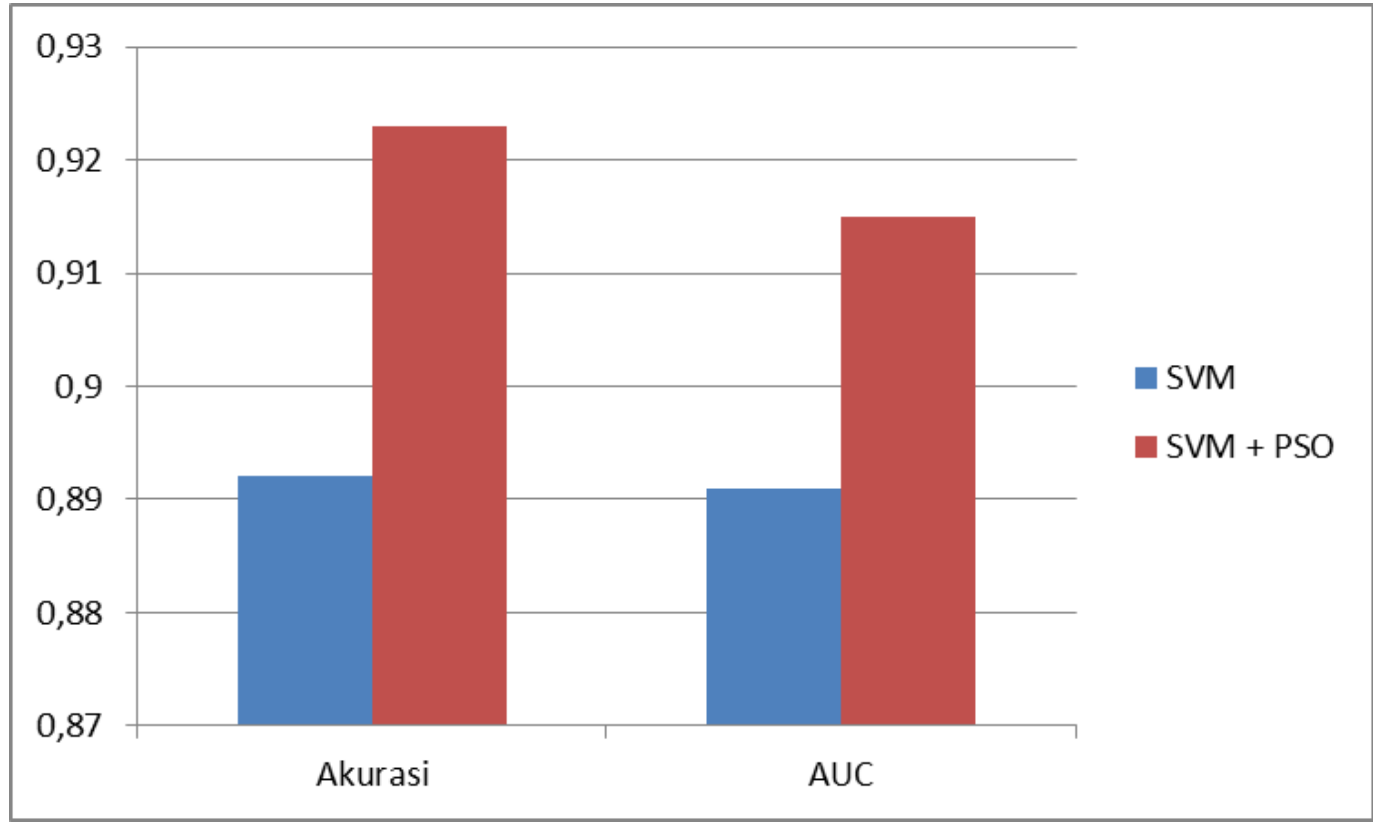

Sumber: Hasil Penelitian (2020)

Gambar 4. Perbandingan Penelitian

\section{Kesimpulan}

Teknik seleksi Fitur PSO diusulkan untuk melihat perbandingan hasil kinerja algoritma klasifikasi Support Vector Machine. Berdasarkan hasil penelitian maka dapat diambil kesimpulan sebagai berikut : a. Nilai akurasi yang dihasilkan oleh model usulan bernilai sangat tinggi yaitu $92.30 \%$ dan model usulan penelitian telah terbukti berhasil mengingkatkan performa algoritma klasifikasi SVM sebesar 2,88\%. b. Nilai AUC yang dihasilkan oleh model usulan bernilai sangat tinggi yaitu 0,915 , nilai AUC sendiri merupakan representasi dari algoritma klasifikasi yang dibangun, artinya, model yang diusulkan pada penelitian ini terbukti berhasil, karena nilai AUC pada penelitian ini mendekati angka 1.

\section{Referensi}

[1] L. Xu, Q. Hua, J. Yu, and J. Li, "Classification of autism spectrum disorder based on sample entropy of spontaneous functional near infra-red spectroscopy signal," Clin. Neurophysiol., 2020, doi: 10.1016/j.clinph.2019.12.400.

[2] J. Jennings Dunlap, "Autism Spectrum Disorder Screening and Early Action," J. Nurse Pract., vol. 15, no. 7, pp. 496-501, 2019, doi: 10.1016/j.nurpra.2019.04.001.

[3] E. Feczko et al., "Subtyping cognitive profiles in Autism Spectrum Disorder using a Functional Random Forest algorithm," Neuroimage, vol. 172, pp. 674-688, 2018, doi: 10.1016/j.neuroimage.2017.12.044.

[4] E. Rydzewska et al., "General health of adults with autism spectrum disorders - A whole country population cross-sectional study," Res. Autism Spectr. Disord., vol. 60, no. January 2018, pp. 59-66, 2019, doi: 10.1016/j.rasd.2019.01.004.

[5] E. Gordon-Lipkin, A. R. Marvin, J. K. Law, and P. H. Lipkin, "Anxiety and mood disorder in children with autism spectrum disorder and ADHD," Pediatrics, vol. 141, no. 4, 2018, doi: 10.1542/peds.2017-1377.

[6] S. M. Zeedyk, G. Rodriguez, L. A. Tipton, B. L. Baker, and J. Blacher, "Bullying of youth with autism spectrum disorder, intellectual disability, or typical development: Victim and parent perspectives," Res. Autism Spectr. Disord., vol. 8, no. 9, pp. 1173-1183, 2014, doi: 10.1016/j.rasd.2014.06.001.

[7] F. W. Lung, B. C. Shu, T. L. Chiang, S. J. Lin, and M. Tusconi, "Prevalence of bullying and perceived happiness in adolescents with learning disability, intellectual disability, ADHD, and autism spectrum disorder: In the Taiwan Birth Cohort Pilot Study," Med. (United States), vol. 98, no. 6, pp. 1-5, 2019, doi: 10.1097/MD.0000000000014483.

[8] S. Qiu et al., "Prevalence of autism spectrum disorder in Asia: A systematic review and meta-analysis," Psychiatry Res., vol. 284, p. 112679, 2020, doi: 
10.1016/j.psychres.2019.112679.

[9] C. Murray, H. Kovshoff, A. Brown, P. Abbott, and J. A. Hadwin, "Exploring the anxiety and depression profile in individuals diagnosed with an autism spectrum disorder in adulthood," Res. Autism Spectr. Disord., vol. 58, no. September 2017, pp. 1-8, 2019, doi: 10.1016/j.rasd.2018.11.002.

[10] J. Zou, Q. Deng, J. Zheng, and S. Yang, "A close neighbor mobility method using particle swarm optimizer for solving multimodal optimization problems," Inf. Sci. (Ny)., vol. 519, pp. 332-347, 2020, doi: 10.1016/j.ins.2020.01.049.

[11] Y. Liang and H. Yu, "PSO-based energy efficient gathering in sensor networks," Lect. Notes Comput. Sci. (including Subser. Lect. Notes Artif. Intell. Lect. Notes Bioinformatics), vol. 3794 LNCS, pp. 362-369, 2005.

[12] J. Wang, Y. Cao, B. Li, H. jin Kim, and S. Lee, "Particle swarm optimization based clustering algorithm with mobile sink for WSNs," Futur. Gener. Comput. Syst., vol. 76, pp. 452-457, 2017, doi: 10.1016/j.future.2016.08.004.

[13] Y. Chen, "Mining of instant messaging data in the Internet of Things based on support vector machine," Comput. Commun., vol. 154, no. February, pp. 278-287, 2020, doi: 10.1016/j.comcom.2020.02.080.

[14] K. Shankar, S. K. Lakshmanaprabu, D. Gupta, A. Maseleno, and V. H. C. de Albuquerque, "Optimal feature-based multi-kernel SVM approach for thyroid disease classification," J. Supercomput., vol. 76, no. 2, pp. 1128-1143, 2020, doi: 10.1007/s11227-018-2469-4.

[15] K. Li, G. Zhou, Y. Yang, F. Li, and Z. Jiao, "A novel prediction method for favorable reservoir of oil field based on grey wolf optimizer and twin support vector machine," $J$. Pet. Sci. Eng., vol. 189, p. 106952, 2020, doi: 10.1016/j.petrol.2020.106952.

[16] Q. H. Ling, Y. Q. Song, F. Han, C. H. Zhou, and H. Lu, "An improved learning algorithm for random neural networks based on particle swarm optimization and input-to-output sensitivity," Cogn. Syst. Res., vol. 53, pp. 51-60, 2019, doi: 10.1016/j.cogsys.2018.01.001.

[17] I. H. Laradji, M. Alshayeb, and L. Ghouti, "Software defect prediction using ensemble learning on selected features," Inf. Softw. Technol., vol. 58, pp. 388-402, 2015, doi: 10.1016/j.infsof.2014.07.005.

[18] Z. A. Rana, M. A. Mian, and S. Shamail, "Improving Recall of software defect prediction models using association mining," Knowledge-Based Syst., vol. 90, pp. 1-13, 2015, doi: 10.1016/j.knosys.2015.10.009.

[19] G. Czibula, Z. Marian, and I. G. Czibula, "Software defect prediction using relational association rule mining," Inf. Sci. (Ny)., vol. 264, pp. 260-278, 2014, doi: 10.1016/j.ins.2013.12.031.

[20] R. S. Wahono and N. S. Herman, "Genetic feature selection for software defect prediction," Adv. Sci. Lett., vol. 20, no. 1, pp. 239-244, 2014, doi: 10.1166/asl.2014.5283.

[21] Ö. F. Arar and K. Ayan, "Software defect prediction using cost-sensitive neural network," Appl. Soft Comput. J., vol. 33, pp. 263-277, 2015, doi: 10.1016/j.asoc.2015.04.045.

[22] Z. Xu, D. Shen, T. Nie, and Y. Kou, "A hybrid sampling algorithm combining M-SMOTE and ENN based on Random Forest for medical imbalanced data," J. Biomed. Inform., p. 103465, 2020, doi: 10.1016/j.jbi.2020.103465.

[23] V. J. L. Gan, I. M. C. Lo, J. Ma, K. T. Tse, J. C. P. Cheng, and C. M. Chan, "Enhanced automatic twin support vector machine for imbalanced data classification," J. Pre-proof, p. undefined-undefined, 2020, doi: 10.1016/j.chom.2020.04.004.

[24] X. Wang, J. Xu, T. Zeng, and L. Jing, "Local Distribution-based Adaptive Minority Oversampling for Imbalanced Data Classification," Neurocomputing, 2020, doi: 10.1016/j.neucom.2020.05.030.

[25] S. Salcedo-Sanz, J. L. Rojo-Álvarez, M. Martínez-Ramón, and G. Camps-Valls, "Support vector machines in engineering: An overview," Wiley Interdiscip. Rev. Data Min. Knowl. Discov., vol. 4, no. 3, pp. 234-267, 2014, doi: 10.1002/widm.1125.

[26] M. Sewak, P. Vaidya, C.-C. Chan, and Zhong-Hui Duan, "SVM Approach to Breast Cancer Classification," Second Int. Multi-Symposiums Comput. Comput. Sci. (IMSCCS 2007), pp. 32-37, 2007, doi: 10.1109/IMSCCS.2007.46.

[27] X. Cai, L. Gao, and F. Li, "Sequential approximation optimization assisted particle swarm 
optimization for expensive problems," Appl. Soft Comput., vol. 83, p. 105659, 2019, doi: 10.1016/j.asoc.2019.105659.

[28] M. Y. Kurniawan and M. E. Rosadi, "Optimasi Decision Tree Menggunakan Particle Swarm Optimization Pada Data Siswa Putus Sekolah," Jtiulm, vol. 2, no. 1, pp. 15-22, 2017.

[29] R. Wajhillah, "Optimasi Algoritma Klasifikasi C4.5 Berbasis Particle Swarm Optimization Untuk Prediksi Penyakit Jantung," Swabumi, vol. I, no. 1, pp. 26-36, 2014. 